\title{
Effect of Hyphal Homogenate of Phytophthora infestans on the Potato-Tuber Protoplasts
}

\author{
Kohei Tomiryama, Ho Shick LeE and Noriyuki Doke \\ 富山宏平*. 李好植*. 道家紀志*：疫病菌磨砕汁液の \\ ジャガイモプロトプラストに対する影響
}

It has been reported that the time from penetration by an incompatible race of Phytophthara infestans to hypersensitive death of the penetrated potato-cell was very short ${ }^{1,2,3)}$. In the quickest case, the death of the infected cell occurred within about $30 \mathrm{~min}$. These results suggested that some biologically active substances may be related to the hypersensitive death of the infected cell in the case of the incompatible host-parasite combination.

In a previous paper ${ }^{1)}$, effects of the hyphal homogenate and culture filtrate of Phytophthora infestans on the potato tuber slices and leaf tissues was reported. The toxic substances in homogenate and culture filtrates of $P$. infestans (race 0 and race 1 ) appeared to be the same as Saveleva and Rubin's endo- and exotoxins ${ }^{4}$. The toxicity of partially purified high-molecular substances of the endo- and exotoxins did not correlate with the host-parasite specificity. In the experiments reported here, we tried to test the effect of the fungal homogenate against the potato-tuber protoplasts, using different race-variety combinations.

Tubers of the potato cultivars Rishiri $\left(R_{1}\right)$ and Irish Cobbler $(r)$ were used. The former cultivar is incompatible with race 0 of Phytophthora infestans and compatible with race 1 . The latter is compatible with both the races. When the tubers of the cultivar "Rishiri" are infected by race 0 , the infected cells hypersensitively die very quickly.

At first, We examined various method to isolate protoplasts from potato leaves and tubers. Protoplasts could be isolated from leaves and also from tubers by using a little modified method of Takebe et al.5).

Maceration of the tubers was carried out by digesting pieces of the sliced tubers with macerozyme, a crude polygalacturonase (preparation from Rhizopus sp., Zen-Nippon-Biochemicals Co.). The maceration medium contained $1.0-0.5 \%$ macerozyme, $0.7 \mathrm{M}$ D-mannitol and $0.3 \%$ potassium dextran sulfate, $\mathrm{pH}$ being adjusted to 5.8 with $2 \mathrm{~N} \mathrm{HCl}$. Four $\mathrm{g}$ (fr. wt.) of the pieces of sliced tubers were placed in $20 \mathrm{ml}$ of the maceration medium in a $100 \mathrm{ml}$ Erlenmeyer flask. The flask was shaken in a water bath at $26-27 \mathrm{C}$ by a reciprocal shaker for $2 \mathrm{~h}$. The sliced-tuber pieces were then placed in $0.7 \mathrm{M}$ mannitol solution containing 2-6\% (Rishiri) and $2 \%$ (Irish cobbler) cellulase (Zen-Nippon-Biochemicals Co.) and $0.1 \mathrm{mM} \mathrm{CaCl}$ ( $\mathrm{pH}$ adjusted to 5.4 with $2 \mathrm{~N} \mathrm{HCl}$ ). The flasks were then shaken overnight at 26-27 C, or otherwise, for $5 \mathrm{~h}$ at the same condition except that the concentration of the enzyme was higher than in the case of overnight shaking. The enzyme solutions were filtered

* Plant Pathology Laboratory, Faculty of Agriculture, Nagoya University, Nagoya, Japan.

1) Tomiyama, K. (1971). In S. Akai and S. Ouchi (ed). Morphological and biochemical events in plant-parasite interaction. Phytopath. Soc. Japan, Tokyo. 2) Kitazawa, K., Inagaki, H. and Tomiyama, K. (1973). Phytopath. Z. 76: 80-86. 3) Tomiyama, K. (1973). Ann. Phytopath. Soc. Japan 39: 73-78. 4) Saveleva, O. N. and B. A. Rubin. (1963). Fiziologia Rastenii 10: 189194. 5) Takebe, I, Otsuki, Y. and Aoki, S. (1968). Plant and Cell Physiol., 9: 115-124. 6) Caten, C. E. and Jinks, J. L. (1968). Can. J. Bot. 46: 329-348. 
through a milipore filter with $0.45 \mu$ pore size before use. The protoplasts were rinsed five times with $0.7 \mathrm{M}$ sterilized mannitol solution containing $0.1 \mathrm{mM} \mathrm{CaCl}_{2}$. The protoplast solution was finally added with ceporan to the concentration of $0.2-0.3 \%$. All these treatments were done under the aseptic condition.

Race 0 and race 1 of $P$. infestans were grown for 12-20 days in a liquid or on an agar medium containing rye extract ${ }^{6}$ ). The mycelia were separated from the medium and several times washed with water. Seven to ten $\mathrm{g}$ (fresh weight) of mycelia was homogenized three times in a French press cooled at $-10 \mathrm{C}$ (at begining of the homogenization) with $0.01 \mathrm{M}$ phosphate buffer at $\mathrm{pH} 7.1$, and then treated with ultrasonic wave for $5 \mathrm{~min}$. Alternatively, the mycelia grown on the rye extract agar (10-18 days) were ground in a mortar with liquid nitrogen and then lyophilized. One $\mathrm{g}$ of the powder was dissolved in $10 \mathrm{ml}$ of $0.01 M$ potasium phosphate buffer, $\mathrm{pH}$ 7.0. The homogenate obtained by the former or the latter method was centrifuged at $3000 \mathrm{rpm}$ for $5 \mathrm{~min}$. The supernatant was centrifuged at $105,000 \times g$ for $40 \mathrm{~min}$. Lipid-like component floating on the supernatant was discarded. The supernatant was again centrifuged at $105,000 \times \mathrm{g}$ for $40 \mathrm{~min}$ and the lipid-like component was again discarded. The supernatant was dialyzed against water overnight at $0 \mathrm{C}$, and then concentrated to $2 \mathrm{ml}$ by using a Sartorius membranefilter. Ceporan and D-mannitol were aded to the concentrations $2 \mathrm{mg} / \mathrm{ml}$ and $0.7 \mathrm{M}$, respectively.

Forty $\mu 1$ each of protoplast solution and fungal component either the supernatant or the precipitate suspension were placed on the hollow made on a slide glass. The slides were incubated at $17-18 \mathrm{C}$ and the toxic effect was examined after a certain time.

The supernatant fraction of homogenate of race 0 gave the most injurious effect on the protoplasts of the cultivar "Rishiri" as compared with the precipitate fraction of both races and the supernatant fraction of race 1 (Fig. 1). Conversely, there was little difference between the effect of homogenates of race 0 and race 1 on the protoplast of the cultivar "Irish cobbler". There seemed to be an apparent correlation between the toxicities of the supernatants to the protoplasts and the hostparasite specificity. However, more careful examination is necessary to conclude that the

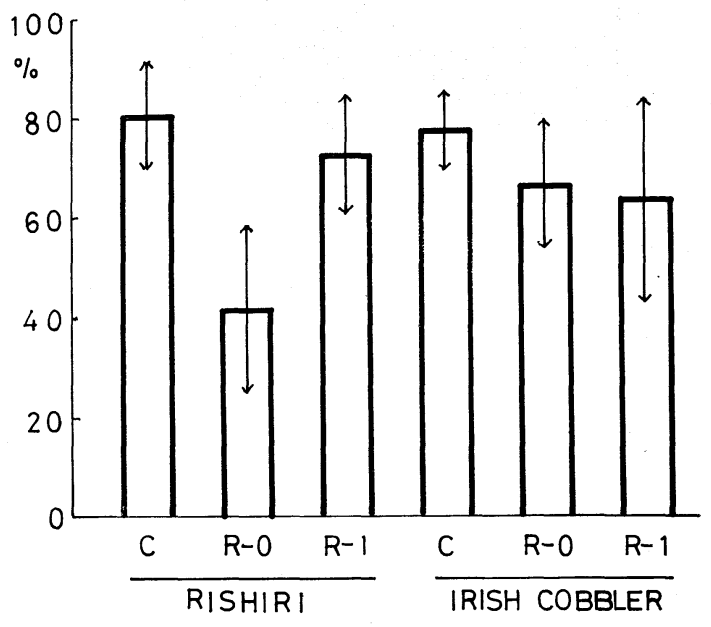

Fig. 1. Percent survival of the protoplasts treated with ultracentrifuge-supernatants of the fungal homogenates $(24 \mathrm{hr}$ after treatments). Average of experiments repeated 6 times.

$\mathrm{c}$ : control (mannitol solution), R-0 : homogenate of race $0, R-1$ : race 1 . Arrows indicate standard deviations. supernatant fraction is related to establishment of host parasite specificity. The protoplasts treated with the supernatant of the homogenate showed granular appearance of the cell membrane, deformation, and finally coagulation and browning of the cell content (Fig. 2).

To test the effect of heat treatment on the toxicity of the supernatant, the Wassermann test tubes containing the supernatant were heated in a water bath and then the resulted turbid solution was used for the assay. To test the effect of ethanol on the toxicity, the supernatant of fungal homogenate was treated twice with ethanol (final concentration $80 \%$ ). The insoluble fraction was dissolved in water and tested for its toxicity. The supernatants lost their toxic activity after heat 

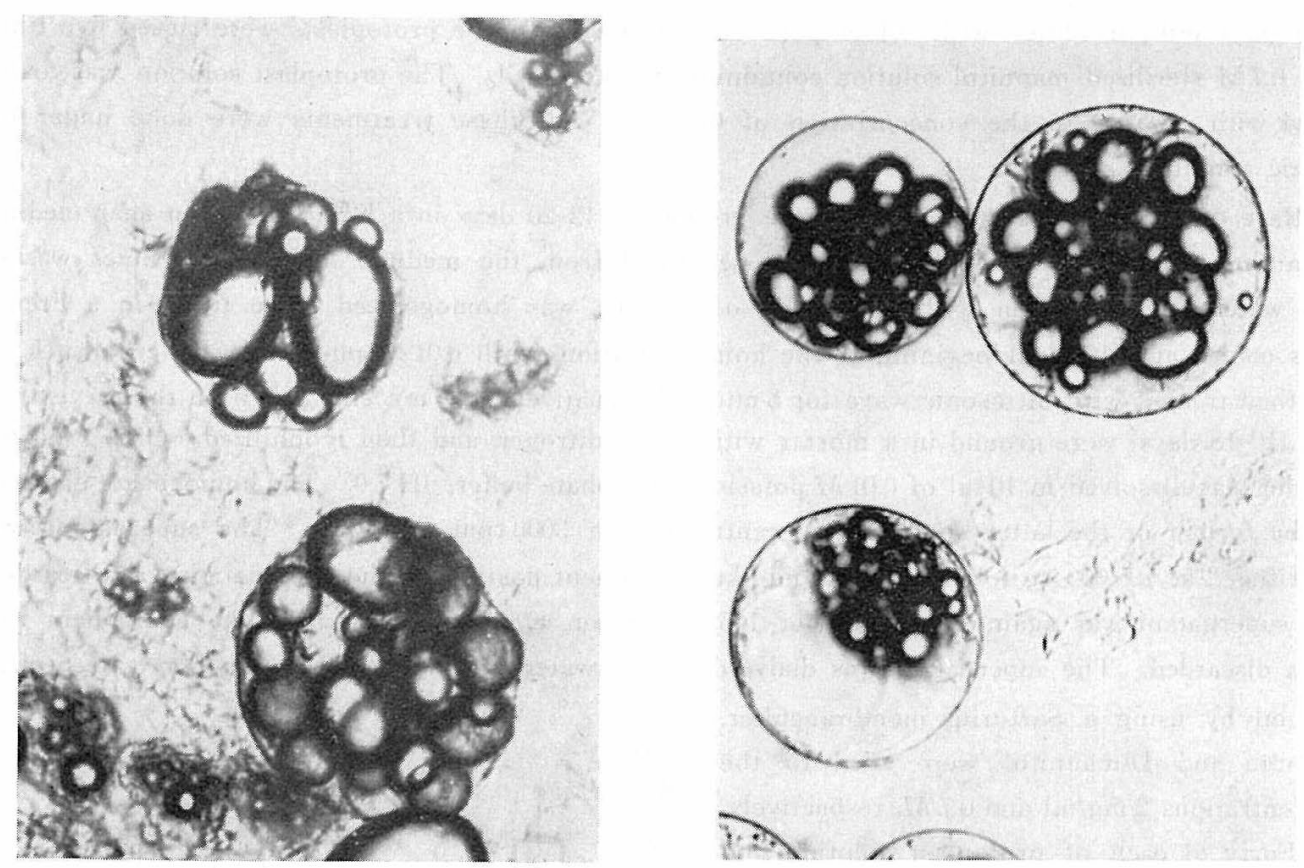

Fig. 2. Protoplasts obtained from potato tubers.

Left: Rishiri (treated and abnormal) Right: Rishiri (normal)

Table 1. Effect of heat treatment on the toxicity of the hyphal components to the protoplasts of cultivar "Rishiri" (percentages of abnormal protoplasts).

\begin{tabular}{|c|c|c|c|c|c|}
\hline & \multicolumn{3}{|c|}{$\begin{array}{l}\text { Ultracentrifuge } \\
\text { supernatant }\end{array}$} & \multicolumn{2}{|c|}{$\begin{array}{l}\text { Ethanol insolulbe } \\
\text { fraction of } \\
\text { ultracentrifuge } \\
\text { supernatant }\end{array}$} \\
\hline & \multirow{2}{*}{ unheated } & \multicolumn{2}{|c|}{ heated at } & \multirow{2}{*}{ unheated } & \multirow{2}{*}{$\frac{\text { heated at }}{70 \mathrm{C}}$} \\
\hline & & $70 \mathrm{C}$ & $90 \mathrm{C}$ & & \\
\hline Mannitol solution & 3.5 & - & - & 11.2 & - \\
\hline Race 0 homogenate & 31.4 & 5.5 & 2.9 & 75.4 & 58.5 \\
\hline Race 1 homogenate & 23.5 & 4.6 & 1.0 & 56.1 & 56.4 \\
\hline
\end{tabular}

Remark : Average of experments repeated three times.

treatment at $70 \mathrm{C}$ or $90 \mathrm{C}$ for $3 \mathrm{~min}$ (Table 1 ). When the supernatants of the fungal homogenates were treated with ethanol (final $80 \%$ ), the precipitates were toxic to the protoplasts of both cultivars. The toxic principles in the ethanol-insoluble fraction seemed rather heat-stable (Table 1). These results suggested that the protoplasts would be useful to investigate the mechanism of specificity between host and parasite.

\section{Acknowledgments}

This research was supported in part by a research grant from the Ministry of Education, Japan. We are grateful to Messers S. Sakaguchi, Y. Umemura, K. Yanagida, K. Kitazawa, N. Ishizaka and N. Sato, Hokkaido Agr. Exp. Sta. Sapporo, for their valuable help. 